\title{
DIRECT SHEAR TEST ON FLY ASH- LIME SOIL MIXTURES
}

\author{
Mahdi Keramatikerman \\ Engineer, Arup Australia, 61-73 \\ Sturt Street, Suncorp Tower, Townsville QLD 4810, Australia
}

Amin Chegenizadeh

Senior Lecturer, Department of Civil Engineering,

Curtin University of Technology, Kent Street, Bentley, Perth, Western Australia 6102, Australia

Hamid Nikraz

Professor, Department of Civil Engineering,

Curtin University of Technology, Kent Street, Bentley, Perth, Western Australia 6102, Australia

\begin{abstract}
Direct shear test run on the mixture of fly ashlime mixed with clay. During this test, the dosage of lime was changed from 5 to $15 \%$. The shear stress at failure were slightly changed.
\end{abstract}

Keywords - Direct Shear, Kaolinite, Lime

\section{INTRODUCTION}

Direct shear test is one of the basic geotechnical test shows the shear strength of the soil against different normal stress [114]. This test is also used for soil stabilization investigations [15-26]. Addition of different by products along with a cementitious agent is very common method to improve mechanical characteristics of the soil [27-35]. Fly ash is an abundant by-product material that widely remains and used in different industry [35-49]. This study aims to investigate effect of addition of fly-ash lime into kaolinite clay.

\section{MATERIALS}

Following materials were used in this study:

\section{a) Flyash:}

The major ingredients of fly ash are $\mathrm{SiO}_{2}$ with approximately $50 \%$ of content of fly ash.

\section{b) Lime}

The Cao was the major ingredients of the employed lime.

$$
\text { c) Clay }
$$

Clay used in this study obtained from a local provider.

\section{COMPACTION TESTING}

Table 1 shows the compaction characteristics of the mixes.
Table 1 Compaction characteristics of mixes

\begin{tabular}{|l|l|l|l|}
\hline Sample Id & Lime & OMC \% & MDD \\
\hline F-L5 & 5 & 30 & 1.27 \\
\hline F-L10 & 10 & 32 & 1.19 \\
\hline F-L15 & 15 & 37 & 1.14 \\
\hline
\end{tabular}

\section{OMC \%}

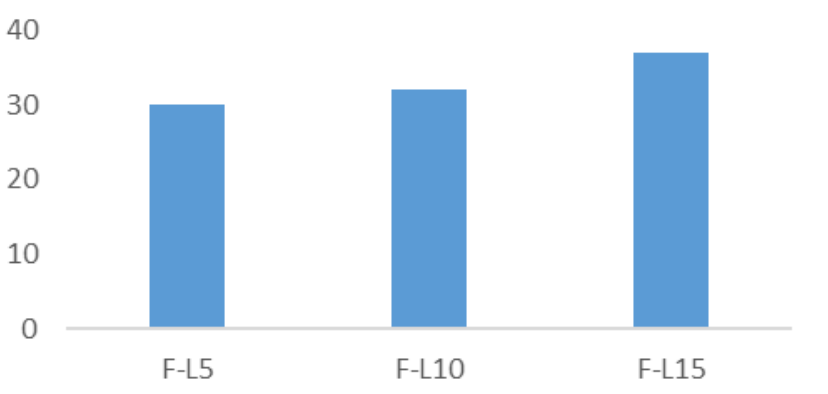

Fig. 1 Compaction characteristics of mixtures optimum moisture content (OMC).

\section{MDD}

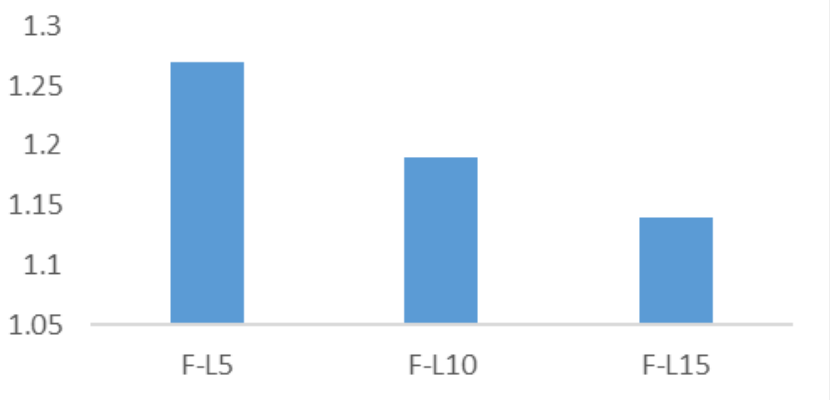




\section{International Journal of Engineering Applied Sciences and Technology, 2020 \\ Vol. 4, Issue 11, ISSN No. 2455-2143, Pages 50-53 \\ Published Online March 2020 in IJEAST (http://www.ijeast.com)}

Fig. 2 Compaction characteristics of mixtures maximum dry density (MDD).

\section{DIRECT SHEAR TEST}

The direct shear test were run on the mixture of flyahs and lime. The lime percentage were changed from $5 \%$ to $15 \%$. The normal stress were $100 \mathrm{kPa}, 200 \mathrm{kPa}$ and $300 \mathrm{kPa}$.

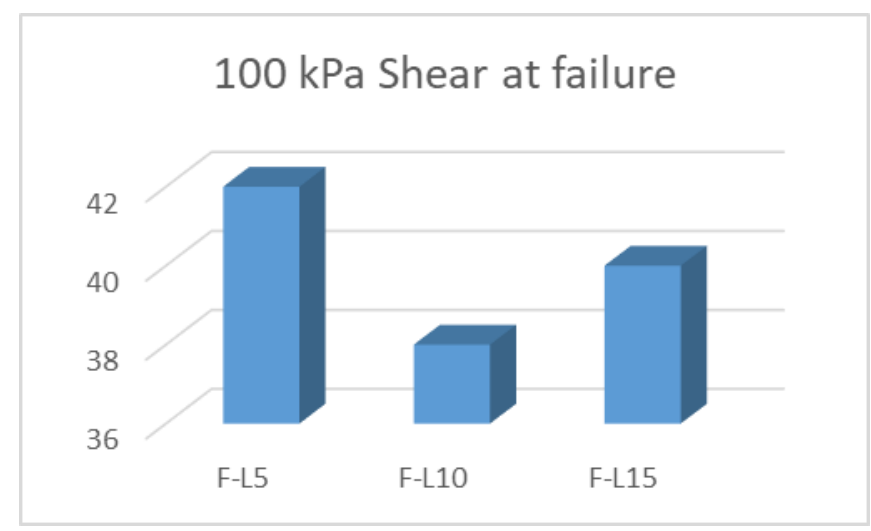

Fig. 3 Shear failure under $100 \mathrm{kPa}$ normal stress.

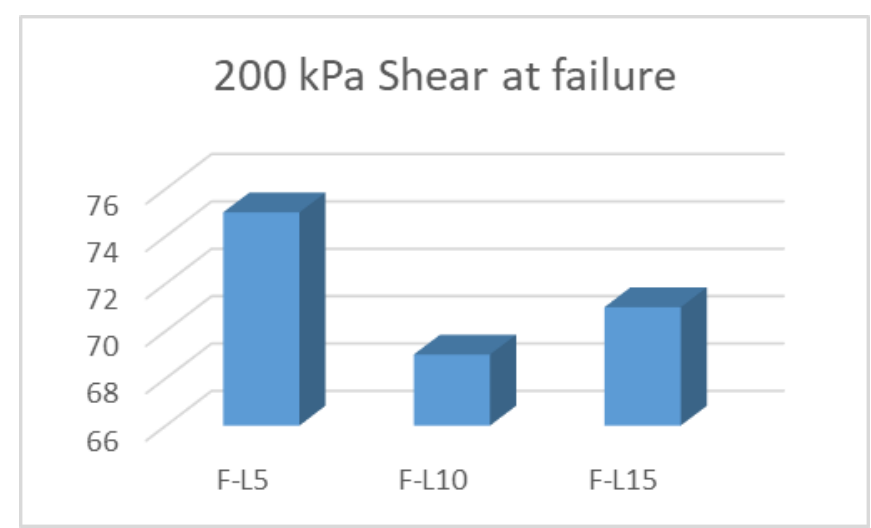

Fig. 4 Shear failure under $200 \mathrm{kPa}$ normal stress.

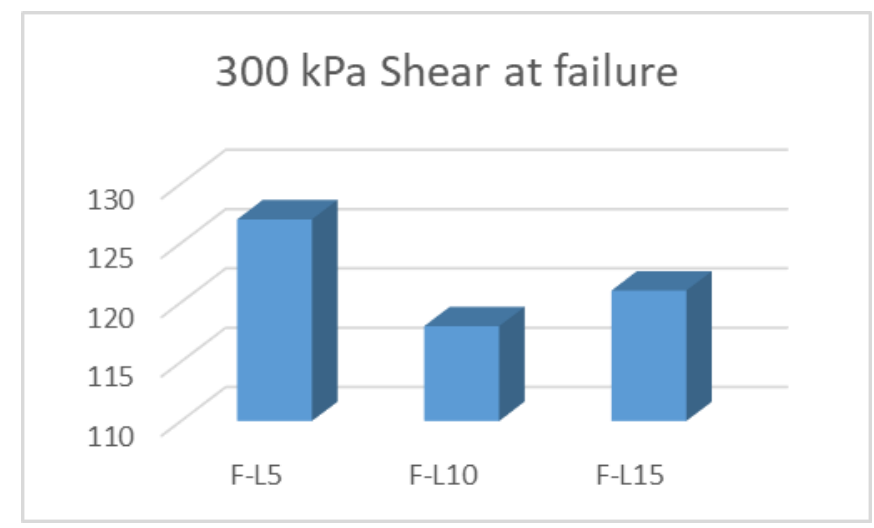

Fig. 5 Shear failure under $300 \mathrm{kPa}$ normal stress.

\section{CONCLUSION}

The compaction results showed that increasing in lime decreases the MDD and increases OMC. The lime effect on shear stress up to $10 \%$ was decreasing and for $15 \%$ showed decreases.

\section{REFERENCES}

[1] Ghosh A, Subbarao C. Strength characteristics of class F fly ash modified with lime and gypsum. Journal of geotechnical and geoenvironmental engineering. 2007 Jul;133(7):757-66.

[2] Mikhail, M., Chegenizadeh, A., Keramatikerman, M., Burns, G., Terzaghi, S., Nikraz, H. (2020). Application of Cane Ash on Compressive Strength of Soil Uncovered to $\mathrm{MgSO}_{4}$. International Journal of Engineering and Advanced Technology (IJEAT) 9(4).

[3] Phanikumar BR. Effect of lime and fly ash on swell, consolidation and shear strength characteristics of expansive clays: a comparative study. Geomechanics and Geoengineering: An international journal. 2009 May 28;4(2):175-81.

[4] Chegenizadeh, A., Keramatikerman, M., \& Nikraz, H. (2017). A Study on Numerical Modelling of Rigid Pavement: Temperature and Thickness Effect. International Journal of Civil and Environmental Engineering, 10(2), 265-269.

[5] Phani Kumar BR, Sharma RS. Effect of fly ash on engineering properties of expansive soils. Journal of Geotechnical and Geoenvironmental Engineering. 2004 Jul;130(7):764-7.

[6] Al-Rkaby AHJ, Chegenizadeh A, Nikraz H. (2016). Directional-dependence in the mechanical characteristics of sand: A Review International Journal of Geotechnical Engineering 10 (5), 499-509

[7] Kumar A, Walia BS, Bajaj A. Influence of fly ash, lime, and polyester fibers on compaction and strength 


\section{International Journal of Engineering Applied Sciences and Technology, 2020 \\ Vol. 4, Issue 11, ISSN No. 2455-2143, Pages 50-53 \\ Published Online March 2020 in IJEAST (http://www.ijeast.com)}

properties of expansive soil. Journal of materials in civil engineering. 2007 Mar;19(3):242-8.

[8] Keramatikerman, M., Chegenizadeh, A., \& Nikraz, H. (2018). Effect of Flyash on Post-Cyclic Behavior of Sand. Journal of Earthquake Engineering, 1-13.

[9] Indraratna AS, Balasubramanian AK, Khan MJ. Effect of fly ash with lime and cement on the behavior of a soft clay. Quarterly Journal of Engineering Geology and Hydrogeology. 1995 May 1;28(2):131-42.

[10] Keramatikerman M, Chegenizadeh A, Terzaghi S. (2019) Review on Effect of Sugarcane Bagasse Ash as an Additive in Construction Industry. 2019. EJGE. Vol.24 Bun. 02.

[11] Kate JM. Strength and volume change behavior of expansive soils treated with fly ash. InInnovations in Grouting and Soil Improvement 2005 (pp. 1-15).

[12] Keramatikerman M, Chegenizadeh A. Effect of particle shape on monotonic liquefaction: Natural and crushed sand. Experimental Mechanics. 2017 Oct 1;57(8):1341-8.

[13] Keramatikerman, M., Chegenizadeh, A., Nikraz, H., \& Sabbar, A. S. (2018). Effect of flyash on liquefaction behaviour of sand-bentonite mixture. Soils and foundations, 58(5), 1288-1296.

[14] Sezer A, İnan G, Yilmaz HR, Ramyar K. Utilization of a very high lime fly ash for improvement of Izmir clay. Building and environment. 2006 Feb 1;41(2):150-5.

[15] Keramatikerman $M$, Chegenizadeh A, Nikraz $H$. (2017). Experimental study on effect of fly ash on liquefaction resistance of sand Soil Dynamics and Earthquake Engineering 93, 1-6

[16] Chegenizadeh, A., Nikraz, H. (2011). "Investigation on strength of fiber reinforced clay" Advanced Materials Research 261-263, pp. 957-963.

[17] Chegenizadeh, A. and H. Nikraz, (2011). "Study on modulus of elasticity of reinforced clay" - Advanced Materials Research. 243-249: pp. 5885-5889, 2011.

[18] Lin DF, Lin KL, Hung MJ, Luo HL. Sludge ash/hydrated lime on the geotechnical properties of soft soil. Journal of hazardous materials. 2007 Jun 25;145(12):58-64.

[19] Chegenizadeh, A. and H. Nikraz, (2011). Composite Soil: Fiber Inclusion and Strength, Journal of Advanced Materials Research 1646

[20] Chegenizadeh, A. and H. Nikraz, (2012). Composite Clayey Sand and Short Fiber, Advanced Materials Research 383, 2764-2769

[21] Chegenizadeh, A., Keramatikerman, M., \& Nikraz, H. (2018). Liquefaction resistance of fibre reinforced lowplasticity silt. Soil Dynamics and Earthquake Engineering, 104, 372-377.

[22] Chegenizadeh A, Keramatikerman M, Panizza S, Nikraz H. (2017). Effect of powdered recycled tire on sulfate resistance of cemented clay. Journal of Materials in Civil Engineering. 2017 Oct 1;29(10):04017160.
[23] Harichane K, Ghrici M, Kenai S. Effect of curing time on shear strength of cohesive soils stabilized with combination of lime and natural pozzolana.

[24] Chegenizadeh, A., Keramatikerman, M., Dalla Santa, G., \& Nikraz, H. (2018). Influence of recycled tyre amendment on the mechanical behaviour of soilbentonite cut-off walls. Journal of cleaner production, 177, 507-515

[25] Chegenizadeh A, Aashish M, Nikraz H, Keramatikerman M. Sulphate Attack on CementedBentonite-Coconut Coir. Results in Engineering. 2020 Mar 3:100111.

[26] Ramesh HN, Siva Mohan M, Sivapullaiah PV. Improvement of strength of fly ash with lime and sodium salts. Proceedings of the Institution of Civil EngineersGround Improvement. 1999 Oct;3(4):163-7.

[27] Amiralian S, Chegenizadeh A, Nikraz H (2012) Laboratory investigation on the effect of lime on compressibility of soil, Proceedings of the International Conference on Civil and Architectural applications (ICCAA'2012) 89-93

[28] Chegenizadeh, A., \& Keramatikerman, M. (2017). Mitigating sulphate attacks in geotechnical engineering Hauppauge, New York, USA Nova Science Publishers. (pp. 1-165).

[29] Keramatikerman M, Chegenizadeh A, Nikraz H. Effect of Slag on Restoration Mechanical Characteristics of Ethanol Gasoline-Contaminated Clay. Journal of Environmental Engineering. 2018 Jul 1;144(7):06018001.

[30] Zha F, Liu S, Du Y, Cui K. Behavior of expansive soils stabilized with fly ash. Natural hazards. 2008 Dec 1;47(3):509-23.

[31] Chegenizadeh A, Keramatikerman M, Panizza S, Nikraz H. (2017). Effect of powdered recycled tire on sulfate resistance of cemented clay. Journal of Materials in Civil Engineering. 2017 Oct 1;29(10):04017160.

[32] Kumar S, Puri VK, Das BM, Devkota BC. Geotechnical Properties of Fly Ash and Lime- Fly Ash Stabilized Coal Mine Refuse. Electronic Journal of Geotechnical Engineering. 2000;5:4.

[33] Chegenizadeh, A., Keramatikerman, M., Miceli, S., Nikraz, H., Salih Sabbar, A. (2020). Investigation on Recycled Sawdust in Controlling Sulphate Attack in Cemented Clay. Appl. Sci., 10, 1441.

[34] Amiralian S, Chegenizadeh A, Nikraz H (2012) Laboratory investigation on the compaction properties of lime and fly ash composite, Proceedings of the International Conference on Civil and Architectural applications (ICCAA'2012) 79-83

[35] Keramatikerman, M., Chegenizadeh, A., \& Nikraz, H. (2017). An investigation into effect of sawdust treatment on permeability and compressibility of soil-bentonite slurry cut-off wall. Journal of Cleaner Production, 162, $1-6$. 


\section{International Journal of Engineering Applied Sciences and Technology, 2020 \\ Vol. 4, Issue 11, ISSN No. 2455-2143, Pages 50-53 \\ Published Online March 2020 in IJEAST (http://www.ijeast.com)}

[36] Chegenizadeh, A., Keramatikerman, M., \& Nikraz, H. (2016). Flexible pavement modelling using Kenlayer. EJGE, 21, 2467-2479.

[37] Du Yanjun ZF. Experiment on improvement of expansive clays with lime-fly ash [J]. Journal of Southeast University (Natural Science Edition). 2007;2.

[38] Keramatikerman, M., Chegenizadeh, A., \& Pu, H. (2017). Effect of atrazine contamination on compressibility and permeability characteristics of clay. Geotechnical Testing Journal, 40(6), 936-950.

[39] Chegenizadeh, A., Keramatikerman, M., Nikraz, H., Importance of Microstructural Analysis in Experimental Soil Stabilization. Global Journal of Engineering Science. 4(5): 2020.

[40] Al-Rkaby AHJ, Chegenizadeh A, Nikraz H. (2017). Anisotropic strength of large scale geogrid-reinforced sand:experimental study Soils and foundations 57 (4), 557-574

[41] Harichane K, Ghrici M, Missoum H. Influence of natural pozzolana and lime additives on the temporal variation of soil compaction and shear strength. Frontiers of Earth Science. 2011 Jun 1;5(2):162-9.

[42] Keramatikerman M, Chegenizadeh A, Nikraz H. Shear strength characteristics of over-consolidated clay treated with ggbfs. Australian Geomechanics Journal. 2018;53(2):141-9.

[43] Brooks RM. Soil stabilization with fly ash and rice husk ash. International Journal of Research and Reviews in Applied Sciences. 2009 Dec;1(3):209-17.

[44] Keramatikerman, M. (2018). Investigations into Effect of By-product Binders in Improvement of Cyclic Behaviour of Soil (Doctoral dissertation, Curtin University).

[45] Guleria SP, Dutta RK. Unconfined compressive strength of fly ash-lime-gypsum composite mixed with treated tire chips. Journal of Materials in Civil Engineering. 2011 Aug 1;23(8):1255-63.

[46] Keramatikerman, M., Chegenizadeh, A., Nikraz, H. How Ground Improvement Addresses the United Nation Sustainable Development Goals: A Review. Current Trends in Civil \& Structural Engineering 5(3): 2020. CTCSE.MS.ID.000613.

DOI: 10.33552/CTCSE.2020.05.000613

[47] Keramatikerman, M., Chegenizadeh, A., Yilmaz, Y., \& Nikraz, H. (2018). Effect of Lime Treatment on Static Liquefaction Behavior of Sand-Bentonite Mixtures. Journal of Materials in Civil Engineering, 30(11), 06018017.

[48] Kayser C, Larkin T, Singhal N. Enhancement of the shear strength of wastewater residuals using industrial waste by-products. Journal of environmental engineering. 2011 Nov 1;137(11):1002-11.

[49] Mikhail, M., Keramatikerman, M., Chegenizadeh, A., Terzaghi, S., Burns, G., Nikraz, H. (2020). Influence of Bagasse Ash on Compaction Behvaiour of Soil.
International Journal of Innovative Technology and Exploring Engineering (IJITEE). 9(5). 